\title{
STATE OF DEVELOPMENT OF TEACHERS' METHOD COMPETENCE IN FOREIGN COUNTRIES
}

\author{
Liudmyla Lyktey ${ }^{1}$
}

\begin{abstract}
In the review article the development trends of teachers' competence in the educational institutions from abroad are analyzed. Based on the scientific analysis of psychological, pedagogical and methodological research, the emphasis is put on the importance of the concept of «competence». The role of competence and its influence over methodical growth, improvement of teachers' professional qualities is defined. It was found that the multi-vector nature for the method competence improvement depends on the conditions of development of scientific and educational space. The necessity of borrowing European experience and continuous integration development of teachers' method competence in Ukrainian educational institutions taking into account the world a scientific and methodological thought is substantiated. It is proven that due to globalization social processes, competence in the foreign scientific and educational environment is rapidly transforming. Thus, the development issue of teachers method competence is relevant for our study, because the concept of «competence» is the subject of numerous scientific researches, meetings, conferences of domestic and international scientists in the European Union and beyond it. The issue of studying and borrowing international practices and world experience that would contribute to the full development of the domestic educational sector remains extremely important. To obtain a complete picture of the development of teachers' method competence, it is advisable to study the experience of foreign scientists and educational institutions from abroad, as well as clarification the essence of numerous methodological and pedagogical concepts. In the context of the study of this problem, we draw attention to the fact that the presentation of world best pedagogical experience, embodied in cooperation, study and promotion is not only relevant and important, but is also very necessary.
\end{abstract}

Key words: competence, method competence, methodological culture, methodological activity, methodical work, development.

JEL Classification: C18, F63

\section{Introduction}

Today, in times of intense educational change, Ukraine is making great efforts to get as close as possible to European educational standards. However, these efforts are accompanied not only by modernization and reformation processes of the Ukrainian educational sector, but they also require a highly educated and professionally pedagogical community. In accordance with the society's needs and demand, a number of new requirements are put forward to teachers of vocational pre-higher education institutions, because teachers are the driving force that forms human capital - a highly educated person. In view of this, an important teachers' task is to borrow world experience in combination with theoretical knowledge and their successful implementation in practice, which is a consequence of improving method competence.

\footnotetext{
Corresponding author:

${ }^{1}$ Ivan Ziaziun Institute of Pedagogical Education and Adult Education of the National Academy of Pedagogical Sciences of Ukraine, Ukraine. E-mail: L.liktej@ukr.net

ORCID: https://orcid.org/0000-0001-7348-4286
}

The purpose of the study is to analyze the trends in the development of college teachers' method competence in the scientific and educational space from abroad. Based on the analysis, there is an aim to find out the importance of borrowing and implementing theoretical, methodological and practical experience in the educational sector of Ukraine.

In foreign and Ukrainian educational discourse, competence is studied mainly as an integral component of professional development and it is described from the perspective of theoretical, empirical, statistical, research methods based on the competence approach.

\section{Presentation of main material}

Nowadays the definition of trends in the development of teachers' method competence, particularly the 
teachers of humanities from vocational pre-higher education institutions, is considered to be a priority adoption, which is implemented to develop Ukrainian education. The right choice of teaching strategy creates the conditions for a proper solution to the problem of the methodological competence development. In the research context of this problem, we pay attention that presentation of the world advanced pedagogical experience embodied in cooperation, studying and popularization acquires importance and necessity. The works of world-class scientists reflect a number of opinions about the teacher's personality, their competencies, in particular:

- the teacher's professional competitive ability (Yu. Liannoi, N. Demyanenko, I. Havrysh, etc.). (Liannoi, 2017; Demyanenko; Havrysh, 2006);

- readiness to realize own potential for successful productive activities in the social and professional spheres; awareness of the importance and personal responsibility for the results of their own activities, the need for its continuous improvement (Yu. Tatur) (Tatur, 2004);

- readiness for systematic transfer of knowledge, skills, abilities; acquisition of new ones (N. Kuzmina) (Kuzmina, 1990);

- readiness and ability to find alternative ways for development, improvement of skills of personalityoriented communication, on the basis of the transformational component of cultural and intercultural components (E. Taylor) (Tatur, 2004);

- possession of methodological tools for students' differentiated training, changes in their own methodological profile in order to improve themselves (D. Hargreaves) (Hargreaves, 2004);

- ability to self-organization in solving certain tasks of professional orientation, self-development, focused on knowledge, values, abilities, volitional decisions, etc (J. Erpenbeck, P. Heyse) (Avsheniuk, Desiatov, Diachenko, et al.).

On the road of the development of 21 st century European education, in 2000 theEuropean Commission approved the targeted program named «the Education and Training 2010» (The Lisbon Strategy), which provided for a fundamental modernization of European education system, including the transformation of education levels and elements. A lot of attention is paid on the issues of improving the education, development of the professional level of teachers and educators, who, according to this document, play a key role in restarting this project. Already in 2003, the European Commission together with the European University Association initiated the creation of a project called «Setting up educational structures $\gg$, according to which the process of learning in higher education was aimed at ensuring the development of general competencies. The developers divided these competencies into three closely related groups: instrumental competencies, interpersonal competencies and systemic competencies, which are intended to form professional competencies as the highest results in European education.

Based on the actions carried out in 2005, the document «Common European Principles for Teacher Competences and Qualifications» was developed, which regulates the course of providing a single approach in order to define common criteria for pedagogical education in Europe. The document provides the main messages for the teacher: to work with others; using knowledge, information and technology; to work in society at the local, regional, national, European levels. In addition, a number of documents was developed that regulated the teachers' educational activities in the coming years. Soon later, in 2018, the Council of the European Union in its Recommendations identified the key competencies that would be needed for a person to be able to work, to realize oneself personally and develop in the period of rapid global change (Recommendations Council).

Studying the European educational experience, we pay attention to the work of Finnish researcher Olli Vesterinen, who analyzed a number of laws and regulations of European countries in order to promote the teaching profession and highlight the most important competencies of teachers, which he combined into five groups: pedagogical and psychological competence, interpersonal competence, special subject-oriented and methodological competence, organizational and intercultural competence. We correlate the proposed competencies of Olli Vesterinen with the concepts that interest us, in particular, methodological culture - Intercultural competence; methodical work and activity - special subject-oriented, pedagogical and psychological competence; methodical competence - methodical competency.

In their scientific works, foreign scientists T. Rudneva and N. Solovova consider the concept of «methodical work» somewhat more narrowly and concisely than the concept of «methodical activity», as they believe that methodical activity is an independent type of pedagogical professional activity of a teacher and involves the implementation of methodological recommendations, instructions, etc., and methodical work, according to scientists, is a pre-planned activity of the teacher, which simultaneously aims to improve existing forms, principles, methods of educational process and develop new (Rudneva, Solovova, 2012). Methodical work and methodical activity are inseparable components that establish the concept of "methodical culture" of the teacher.

In our opinion, Methodological culture is a phenomenon that does not diminish the importance of method competence and plays an important role in its development. Thus, N. Nikula interprets this concept as the teacher's ability to build their own 
professional and pedagogical activities on the basis of psychological and pedagogical knowledge (Nikula, 2002). Complementing this scientist's opinion, L. Plekhanova defines methodological culture as a socioprofessional characteristic, which is a reflection of a high level of pedagogical activity, methodically conscious use of pedagogical tools in teaching, creation and updating of new pedagogical values, etc. (Plekhanova, 2012).

Methodological culture, methodological activity, method competence, methodical accumulation and improvement of skills in order to carry out highquality educational activity as well as borrowing of world experience have considerable influence over the development of the teacher's personality in a professional and methodological context which is directed on the systematic analysis of own pedagogical activity according to standards, which will be partially considered.

Today, the United States, the United Kingdom of Great Britain, the Federal Republic of Germany, Denmark and others are the leading world leaders in the field of education. In order to popularize the international pedagogical experience in Ukraine, domestic scientists and scholars cover a number of studies about education in foreign countries, because it is education that has always attracted attention.

Thus, the US experience shows that education can be the highest example of a decentralized education system with competent management, and higher education, however can be broad autonomy, assisted by the state. This is the main difference between education in the United States and Ukraine, as the accreditation of colleges, control by government institutions is voluntary (in Ukraine, such procedures are mandatory). Teachers and students freedom comes first. Higher education institutions, in particular colleges, are characterized by autonomy, diversity, flexibility, variability, commercialization, continuity, and so on. There are a number of requirements and criteria for the teachers' activity. However, the teacher is free to make management decisions, choosing methods, techniques and principles of teaching. Typically, the assessment of the activities of colleges and universities in the United States is based on the performance of the institution, candidates access to education, economic and financial activities, and the quality of teaching staff. Therefore, not only the quality of the teachers teaching activity, the availability of educational content developed by them, but also their scientific and publishing activity and their own scientific degree are assessed. The US education standards, requirements for teachers of educational institutions are very different from European ones; however, meet the requirements of the time and the needs of modern society. There is an intensive interaction of educational institutions with the labor market, and the issues of cooperation with stakeholders are becoming very important.
The educational experience of Great Britain shows that the professional standard in this country is developed on the basis of the competence approach. The model of professional competence is represented by a set of competencies, which, in our opinion, are closely related: cognitive competencies (formal and informal knowledge); functional competence (skills or know-how); personal competencies (behavioral competencies); meta-competencies (ability to cope with uncertainty, edifications and criticism); ethical competence (Avsheniuk, Desiatov, Diachenko, et al.). It should be noted that, unlike other countries, teaching at universities is not widespread here, but tutoring, which does not involve student training, but management and mentoring in the form of group discussions and individual consultations during which the student develops a number of professional skills and competencies. A tutor can be not only a mentor, but also a master teacher, a teacher-curator, a teacheradministrator, a teacher-concierge. This system of work requires a teacher with a high level of professional and qualified competencies. It also regulates the processes that affect his/her self-education and selfimprovement, forms a teacher-innovator capable to think, to teach pragmatically and to be an integral part of the modern educational community. Unlike tutors, facilitators conduct seminars according to the courses chosen by the students. Such seminars involve a combination of theoretical and practical activities. On the basis of theoretical knowledge, teachers together with stakeholders develop practical tasks. This type of cooperation helps to coordinate the development of professional competencies of the teacher and future specialists.

The experience of raising the teachers professional level at universities and colleges of the United Kingdom of Great Britain (Wales) is interesting, as educational institutions with scientific, academic and pedagogical staff are responsible for the growth of professional competence. Most of them have their own research departments, centers and administrative departments, which take care of raising the teachers professional level. We consider the discussion with the teaching staff their individual personal needs to be a key remark for raising the teachers methodological level in this country. Using algorithms of teachers professional development, a university certification takes place, which plays the role of motivator. Professional development is increased annually, clearly according to the developed plans. The teaching staff takes responsibility for improving their own professional level and career growth, looks for new opportunities for development and improvement of competencies, determines their learning needs independently, taking into account the experience of certification. The Centre for Didactics in Higher Education of England provides considerable methodical help to teachers. Their task is 
to organize courses, seminars, trainings, pedagogical and scientific meetings, etc., in order to promote the personal experiences of each teacher, since holding courses according to another teacher's recommendations or using developed textbooks is considered humiliating.

This practice also started working in Ukraine. The regulatory document that clearly prescribes this condition is the Resolution of the Cabinet of Ministers of Ukraine № 800 of 21.08.2019 «Some issues of professional development of pedagogical and scientificpedagogical workers $\gg$ with changes according to the Resolution of the Cabinet of Ministers № 1133 of 27.12.2019, where in p. 8 it is stated that the amount (duration) of professional development of pedagogical and scientifically pedagogical staff is set in hours and/or credits of the European Credit Transfer and Accumulation System (one ECTS credit - 30 hours per year) under the accumulative system. That is, within 5 years the college teacher raises his professional level and accumulates 5 ECTS credits (150 hours). The main types of advanced training are training in the in-service training program, including participation in seminars, workshops, trainings, webinars, master classes, etc. (Deiaki pytannia pidvyshchennia kvalifikatsii pedahohichnykh i naukovo-pedahohichnykh pratsivnykiv).

Analyzing the experience of Denmark, we see that in this highly developed country there are also a number of requirements for teaching staff, in particular, the teacher must be highly qualified (master, doctor), conduct an active research, participate in social and scientific projects, exchange experiences, daily improving the competencies. According to these criteria, teachers are divided into adjuncts (contract for 3 years), lecturers, associate professors, professors. An important aspect of the professional competence development of pedagogical staff is that at the state level the partnerships of higher pedagogical education institutions and schools are expanded and strengthened. It helps to improve the quality of work of both structures. For the stable systematic development of the teacher, the transition to continuous pedagogical education has been made (Roliak, 2010).

We also pay attention to the education system of Finland. In the last century, the main goal of the Finnish government was to reform the education sector on the basis of traditional education. The initial stages of the educational reform included specialized teacher training programs, which became an integral part of Finland's academic higher education. Education in such programs took place only in accredited universities. It gave a great impulse to the continuity of pedagogical education and lifelong learning. At the legislative level, the issue about the requirements for teaching staff at schools, colleges and universities was settled. Only a teacher with a master's degree can become an educational worker at school, a licensee or a doctor is needed at college, while only a doctor should work at university. At universities, the emphasis is put on training researchers in the fundamental and human sciences.

Obtainment of pedagogical education for specialists applying for the positions of teachers at colleges and universities is regulated by target competencies and qualification requirements. Teachers of vocational colleges and universities have a whole list of qualification requirements: a high level of professional competence, humanity, individualization and differentiation in training students, continuing educational development and more.

The tasks for the teacher set by the state is the ability to teach students how to think and act on the basis of theoretical knowledge and research, to justify pedagogical decisions with formal and systematic arguments, to use a practice-oriented component and so on (Avsheniuk, Desiatov, Diachenko, et al.). Such programs are reinforced by a number of competencies that are implemented through training in traditional, innovative, alternative, visual and practical methods. An important aspect of success is interactivity, which is the basis of Finnish education. According to K. Kotun, the main approaches to the implementation of continuous development are socio-cultural, resourcebased and professional, continuous analytical, legislative, competent, certified, innovative and ethno-national, liberal and civic (Kotun, 2020).

Properly chosen strategy and implementation of educational modernization processes in Finland has led to the emergence of the most successful educational system in Europe, which should be looked up to. In order to borrow and overspread this practice in the domestic educational space, in 2018 the State Standard of Primary Education was adopted, which is based on the education development through a competent approach. Already in 2019, a joint Ukrainian-Finnish project «Learning an together. Finnish project support NUSH. New Ukrainian School», which was implemented with the assistance of the company FCG International Ltd, and the University of Helsinki and the Ministry for Foreign Affairs of Finland. This project involved teachers, lecturers, principals, rectors, a number of educators, who in the future would act as trainers in educational institutions in order to qualitatively implement educational changes within a competent approach.

The work of the education sector of the Federal Republic of Germany is based on the Framework Law for Higher Education. The activities of educational institutions are detailed in so-called land laws $\ll$ On teacher education». Requirements for teachers from higher education pedagogical institutions in Germany are extremely high. Every teacher in an educational institution must have fundamental competencies. According to the Germans, the most important 
fundamental competencies are intellectual knowledge, which involves lifelong learning; educational competence that determines the ability to learn; method competence, which is aimed at improving language competence and mastering IT. At the same time social competencies are developed in order to establish social cohesion, the ability to work in a team, conflict resolution; valuable orientations that promote social, democratic and individual values (Kubenko, 2010).

It should be noted that every year social needs change, and the teachers' competencies in Germany assume a new significance and shade. Therefore, in connection with the world events of the last decade (military conflicts, social migration, etc.) in 2016 in some cities of Germany with the assistance of the Council of Europe the program designed to spread a culture of democracy, including in educational institutions, began to be actively implemented because from the German educators point of view, education is a long-term investment. Specialists working with the Council of Europe have developed three methodological volumes about the competencies and their implementation. The first manual contains a model of the most relevant competencies, which consists of twenty such examples. These competencies were divided into four areas - values, attitudes, skills, knowledge and critical understanding - and supplemented with information about the model bases, a process description of its development and ways for the future use. The second volume contains definitions about educational goals and outcomes for each of the competencies in particular. The third is advice about the use of the competency model in the educational space (Demyanenko).

Ukraine does not stay away from the modernization of the education sector. At the initial stage of implementation of NUS (New Ukrainian School) reforms, in cooperation with the European Education Fund, the program "Schools for Democracy: Supporting Education Reforms in Ukraine" was presented and a number of trainings «Development of Civil and Social Competences in the Teacher Training System in Ukraine», «Developing and Assessing competence in NUS: Framework of competences for democratic culture», etc. for trainers of the educational institution network in Ukraine and representatives of postgraduate pedagogical education institutions. Such a platform was launched to accelerate Ukraine's integration into European education standards. According to N. Avsheniuk research, it is the European educational system that forms the «European professionalism» of a teacher who must have a «European approach». In the field of his subject, he studies the core topics of the curriculum in the European perspective, exchanges the content and teaching methods his subject with colleagues from other European countries and at the same time pays attention to the ways of teaching and education traditions in different countries by learning them (Avsheniuk, Desiatov, Diachenko, et al.). The possibility of borrowing European pedagogical experience involves expanding and improving the method competence development of teachers of humanities at colleges with a focus on European professionalism and professional development.

In the psychological and pedagogical literature it is noted that «professional development» is a consequence of the formation and growth of professional knowledge, skills, abilities and personal qualities, i.e. competencies. It is a process when the teacher independently or together with his/her colleagues reviews, updates, expands his/her own responsibilities according to the teaching purpose, as well as he/she critically develops knowledge, skills, professional thinking, planning and practice of working with children, youth and colleagues at each stage of his/her professional life (Day, 1999).

\section{Conclusions}

Therefore, analyzing the world educational practice, we can conclude that an important issue is the method competence of teachers, although we consider not so much the method competence of the teacher as the ability to develop and improve it in a wide professional range. Emphasizing the scientific works of foreign researchers, we note that there is no such thing as «method competence». However, we often meet the concepts of «competence», «activity», «development», «culture» and so on.

\section{References:}

Avsheniuk, N. M., Desiatov, T. M., Diachenko, L. M., Postryhach, N. O., Pukhovska, L. P., \& Sulyma, O. V. (2014). Competence approach to teacher training in foreign countries: theory and practice: monohraph. Kirovohrad: Imeks-LTD, $280 \mathrm{p}$.

Day, S. (1999). Developing Teachers: The Challenge of Lifelong Learning. London: Falmer Press, 239 p.

Demyanenko, N. General pedagogical training of teacher in the history of a higher school of Ukraine (XIX - first quarter XX c.). Doctor of Science Dissertation. Kyiv, 469 p.

Hargreaves, D. H. (2004). Personalizing learning: Next steps in working laterally. London. Specialist schools Trust, $128 \mathrm{p}$.

Havrysh, I. V. (2006). Theoretical and methodological bases of forming of readiness of future teachers to innovative professional activity. Doctor of Science Dissertation. Kharkiv, $572 \mathrm{p}$. 
Kotun, K. (2020). Adult education: theory, experience, prospects. Adult Education: Theory, Experience, Prospects, vol. 1(17), p. 134.

Kubenko, I. M. (2010). What is competence and how it is understood in education. Appendix to the journal «Theory and Methods of Education Management», vol. 1.

Kuzmina, N. V. (1990). Professionalism of the personality of the teacher and the master of industrial training. Kyiv: Vyisshaya shkola, 119 p.

Liannoi, Yu. (2017). Theoretical and Methodological Foundations of Professional Training of Future Masters in Physical Rehabilitation at Higher Educational Establishments. Doctor of Science Dissertation, National Pedagogical Dragomanov University, 663 p.

Nikula, N. (2002). Formation of innovative activity. Specialist, vol. 12, pp. 17-18.

Plekhanova, L. A. (2012). Development of Methodological culture of a Lecture of an Additional Education Institution. Modern problems of science and education, vol. 2, pp. 43-47.

Recommendations Council. Council Recommendations of 22 May 2018 on key competencies for lifelong learning (Text with EEA relevance) (2018/C189/01). Available at: https://eur-lex.europa.eu/legal-content/EN/ TXT/PDF/?uri=CELEX:32018H0604(01)\&from=L

Roliak, A. (2010). Teacher training in Denmark: guidelines. Kamianets-Podilskyi: sole proprietor Sysyn O.V., 48 p. Rudneva, T. I., \& Solovova, N. V. (2012). The Managament of Methodological Work in an Institutionof Higher Education: Theary and Experience. Vesnik of Samara State University, vol. 2-1 (93), pp. 151-155.

Tatur, Yu. H. (2004). Competence in the structure of the quality model of specialist training. Vysshee obrazovanye sehodnia, vol. 3, pp. 20-26.

Taylor, E. W. (1994). Intercultural competence: A transformative learning process. Adult Education Quarterly, vol. 44(3). R, pp. 154-174.

Deiaki pytannia pidvyshchennia kvalifikatsii pedahohichnykh i naukovo-pedahohichnykh pratsivnykiv. Available at: https://zakon.rada.gov.ua/laws/show/800-2019-\%D0\%BF 